\title{
Analisis Hasil Belajar Matematika Siswa Kelas VIII SMP Pada Pokok Bahasan Statistika Dikaitkan Dengan Intelligence Quotient (IQ)
}

\author{
Hisyam Ihsan ${ }^{1, a)}$, Rusli $^{1, b)}$, dan Selvi Rahmatia ${ }^{1, c)}$ \\ ${ }^{1}$ Jurusan Matematika, Fakultas MIPA, Universitas Negeri Makassar \\ a)hisyam.ihsan@unm.ac.id \\ b) rusli@unm.ac.id \\ ${ }^{c)}$ selvirahmatia12@gmail.com
}

Abstrak. Penelitian ini bertujuan untuk mengetahui hubungan antara hasil belajar matematika dan tingkat kecerdasan siswa. Pengambilan subjek penelitian ini adalah siswa kelas VIII di salah satu SMP di Makassar. Pengambilan subjek dilakukan dengan memberikan tes kepada siswa kelas VIII 5 yang kemudian dari hasil tersebut dipilih 3 subjek penelitian berdasarkan kategori yang ada. Instrumen yang digunakan adalah tes hasil belajar dengan pokok bahasan statistika yang memuat 5 butir soal dan tes IQ yang mетиat 38 soal. Hasil penelitian yang dilakukan menunjukkan bahwa pada siswa kelas VIII 5 terdapat pengaruh secara signifikan terhadap hasil belajar dan kecerdasan intelegensi siswa sehingga memperoleh hasil yang beragam. Terdapat juga satu siswa yang IQnya tinggi tapi hasil belajarnya rendah.

Kata Kunci: mix methods, Kecerdasan Intelegensi, hasil belajar

Abstract. This study aims to determine the relationship between mathematics learning outcomes and student intelligence levels. The subjects of this study were VIII grade students in one of the junior high schools in Makassar. Taking the subject by giving a test to students of class VIII 5 then from the results, selected 3 subjects based on existing categories. The instrument used was a learning achievement test containing 5 questions and an IQ test containing 38 questions. The results of the research showed that the VIII grade students had a significant influence on student learning outcomes and Intelligence Quotient so it obtains diverse results. There is also one student who has a high IQ but low learning outcomes.

Keywords: mix-methods, intelligence quotient, learning outcomes

\section{PENDAHULUAN}

Hasil belajar adalah kemampuan yang dimiliki siswa setelah ia menerima pengalaman belajarnya (dari tidak tahu dan dari tidak mengerti menjadi mengerti) (Prianto, 2013). Selain itu, hasil belajar adalah puncak dari kegiatan belajar yang berupa perubahan dalam bentuk kognitif, afektif dan psikomotorik dalam hal kemampuan tentang bilangan, hubungan-hubungan konsep dan logika yang berkesinambungan serta dapat diukur atau diamati (Suhendri, 2011). Maka hasil belajar adalah suatu hasil yang diperoleh siswa setelah siswa tersebut melakukan kegiatan belajar dan pembelajaran serta bukti keberhasilan yang telah dicapai oleh seseorang yang dinyatakan dalam simbol, huruf maupun kalimat.

Hasil belajar siswa dipengaruhi oleh kemampuan siswa (internal) sebesar 70\% dan dipengaruhi lingkungan (eksternal) sebesar 30\% (Clark, 1981). Akan tetapi, faktor eksternal dan internal akan saling berhubungan dan saling mendukung dalam pencapaian hasil belajar siswa. Faktor internal meliputi intelegensi, motivasi, kebiasaan, kecemasan, dan minat. Sedangkan faktor eksternal meliputi lingkungan keluarga, lingkungan sekolah, lingkungan masyarakat, dan keadaan sosial ekonomi (Sudjana, 2005). Pada faktor internal yang mempengaruhi hasil belajar siswa, penelitian ini mengambil satu faktor yaitu intelegensi. 
Intelegensi merupakan salah satu faktor internal yang secara umum dikenal dapat mempengaruhi hasil belajar. Intelegensi adalah kemampuan yang dimiliki oleh seseorang dengan menggunakan nalar dan gagasan secara rasional dan terarah agar dapat memecahkan suatu masalah sehingga dapat mencapai tujuan. Intelegensi seseorang khususnya siswa dapat diukur melalui tes Intelligence Quotient. Intelligence Quotient (IQ) merupakan skor yang diperoleh dari tes intelegensi yang sudah distandarisasi sebagai ukuran tingkat kecerdasan seseorang yang berkaitan dengan usia mental dan usia sebenarnya.

Intelligence Quotient (IQ) adalah satu indeks tingkat relative kecermelangan anak, setelah ia dibandingkan dengan anak-anak lain yang seusianya (Chaplin, 2010). Pengukuran intelegensi yang pertama dilakukan oleh Binet, pengukuran yang digunakan oleh binet mengambil perbedaan antara usia mental (MA) dan usia kronologis (CA). Binet dibantu dengan Simon mengklasifikasikan tingkat IQ menjadi 8 golongan. Lalu pada 1914 Stern menyempurnakan tes IQ Binet, Stern mengembangkannya dengan istilah IQ yang menggambarkan intelegensi sebagai rasio antara usia mental dengan usia kronologis dengan rumus: $I Q=\frac{M A}{C A} \times 100$ (Aji, 2012). Angka hasil tes IQ berikut tersaji pada Tabel 1.

Beberapa peneliti mengangkat tema menyangkut hasil belajar dan tes IQ, seperti Putra (2015) dalam penelitiannya menunjukkan bahwa besarnya konstribusi (sumbangan) dari variabel intelegensi adalah sebesar 56,6\% sedangkan sisanya 43,4 \% merupakan pengaruh dari faktor lain. Artinya ada hubungan secara signifikan dari tingkat intelegensi terhadap hasil belajar matematika siswa. Faktor intelegensi berpengaruh sangat nyata terhadap hasil belajar, semakin tinggi intelegensi yang diberikan maka akan semakin tinggi hasil belajar matematika mereka.

TABEL 1. Klasifikasi Kecerdasan (IQ).

\begin{tabular}{cc}
\hline Interval & Predikat \\
\hline 140 keatas & Sangat Cerdas \\
$120-140$ & Cerdas \\
$110-120$ & Pandai \\
$90-110$ & Normal \\
$70-90$ & Bodoh \\
$50-70$ & Debil \\
$30-50$ & Embisil \\
Dibawah 30 & Idiot \\
\hline
\end{tabular}

Hasil yang serupa dijumpai dalam penelitian yang dilakukan Sukiarti (2009) yang menunjukkan bahwa terdapat hubungan positif yang signifikan antara intelegensi dengan prestasi akademik. Diperoleh bahwa secara parsial intelegensi dan motivasi belajar berpengaruh sangat nyata terhadap prestasi akademik dan konstribusi (sumbangan) dari variabel intelegensi yang cukup besar. Hal ini terjadi karena seseorang yang memiliki intelegensi baik (IQ-nya tinggi) umumnya mudah belajar dan hasilnya pun cenderung baik. Sebaliknya orang yang intelegensinya rendah cenderung mengalami kesukaran dalam belajar, lambat berpikir, sehingga prestasi akademiknya pun rendah.

Penelitian ini mengambil fokus pada hasil belajar matematika dan tingkat kecerdasan yang dimiliki siswa. Siswa diberi tes yang bertujuan untuk melihat bagaimana hubungan antara hasil belajar matematika dan tingkat kecerdasannya pada pokok bahasan Statistika di salah satu sekolah menengah pertama di Makassar.

\section{METODE PENELITIAN}

Jenis penelitian ini adalah penelitian deskriptif dengan menggunakan pendekatan kuantiatif dan kualitatif. Penelitian ini dilaksanakan di salah satu sekolah menengah pertama di makassar kelas VIII. 
Siswa yang telah diberikan tes IQ dan tes hasil belajar kemudian diambil masing-masing dua untuk kategori yang IQnya tinggi, sedang, rendah. Setelah itu, siswa diwawancara terkait hasil tes mereka dan kepribadian siswa selama di sekolah dan di rumah.

Teknik pengumpulan data dalam penelitian ini meliputi tes dan wawancara. Pemberian tes kepada 22 siswa yang kemudian dipilih 6 subjek yang sesuai dengan kategori yang ditetapkan. Sedangkan, wawancara bertujuan untuk menguatkan dan menulusuri informasi yang telah didapatkan saat pemberian tes pada subjek. Instrumen yang digunakan adalah tes hasil belajar dan tes IQ.

Adapun analisis data yang digunakan pada penelitian ini meliputi: (1) Analisis data kuantitatif, (2) Analisis data kualitatif. Analisis tes IQ dan hasil belajar secara manual diperiksa hasilnya dan digunakan untuk menentukan subjek yang ingin dipilih. Adapun pada analisis data kualitatif dilakukan dengan pengumpulan data dan wawancara. Setelah data terkumpul selanjutnya penarikan kesimpulan data yang sudah dikumpulkan dan memverfikasi kesimpulan tersebut.

\section{HASIL DAN PEMBAHASAN}

\section{Hasil tes IQ dan hasil belajar peserta didik}

Setelah memeriksa hasil belajar dan IQ dari peserta didik, kemudian untuk melihat apakah terdapat perbedaan yang signifikan terhadap hasil belajar matematika peserta didik yang mempunyai kecerdasan intelegensi tinggi, sedang, dan rendah dianalisis menggunakan statistik inferensial menggunakan SPSS. Pada analisis statistik inferensial ini terlebih dahulu diuji kenormalitasan datanya guna untuk melihat apakah data tersebut berdistribusi normal. Setelah ditemukan bahwa data berdistribusi normal dilanjutkan dengan menguji kehomogenitasannya lalu dilanjutkan dengan uji ANOVA satu jalur.

Hasil tes IQ dan hasil belajar peserta didik kelas VIII 5 diperoleh data pada Tabel 2:

TABEL 2. Hasil Tes Peserta Didik.

\begin{tabular}{|c|c|c|c|c|c|}
\hline No. & Tes & & Tinggi & Sedang & Rendah \\
\hline 1. & IQ & & 3 & 11 & 8 \\
\hline 2. & Hasil Belajar & & 8 & 4 & 10 \\
\hline \multicolumn{6}{|c|}{ TABEL 3. Uji Homogenitas } \\
\hline & Levene Statistics & df1 & df2 & Sig. & \\
\hline & .092 & 2 & 19 & .912 & \\
\hline
\end{tabular}

Pada Tabel 3, dengan hipotesis apabila nilai signifikan lebih besar dari 0.05 maka data homogen, dan didapatkan nilai signifikan sebesar 0.912 ini berarti data homogen sehingga dapat disimpulkan bahwa pengujian variabel IQ dan hasil belajar mempunyai varian yang sama atau homogen. Dengan demikian dapat dilanjutkan dengan Uji ANOVA satu jalur.

TABEL 4. Uji ANOVA Satu Jalur menggunakan SPSS

\begin{tabular}{cccccc}
\hline & Sum of Squares & df & Mean Square & F & Sig. \\
\hline Between Groups & 4725.000 & 2 & 2362.500 & 56.700 & .004 \\
Within Groups & 125.000 & 3 & 41.667 & & \\
Total & 4850.000 & 5 & & & \\
\hline
\end{tabular}

Pada Tabel 4, diketahui bahwa variasi antar kelompok atau between groups lebih besar dari variasi di dalam kelompok atau within groups, artinya nilai mean antara hasil belajar siswa menunjukkan adanya perbedaan, begitupun dengan tes IQ-nya. Kemudian pada nilai F hitung adalah sebesar 56.700 dengan nilai signifikan sebesar 0,004. Ini menunjukkan pada taraf nyata $=0,05 \mathrm{H}_{0}$ ditolak, sehingga kesimpulan yang didapatkan adalah ada perbedaan yang signifikan pada hasil belajar berdasarkan ketiga kelompok intelegensi tersebut. 
TABEL 5. Output SPSS Untuk Analisis Regresi Linear Sederhana

\begin{tabular}{cccc} 
& Model & t & Sig. \\
\hline 1 & (Constant) & 1.304 & .207 \\
& IQ & 3.377 & .003 \\
\hline
\end{tabular}

Berdasarkan Tabel 4 diketahui nilai signifikansi (Sig.) sebesar 0.003 lebih kecil dari probabilitas 0,05 , sehingga terdapat pengaruh intelegensi terhadap hasil belajar. Lalu pada nilai t hitung sebesar 3,377. pada distribusi nilai $t$ tabel didapatkan nilai $t$ tabel sebesar 2,085. Karena nilai $t$ hitung sebesar 3,377 lebih besar dari 2,085, sehingga $\mathrm{H}_{0}$ ditolak dan $\mathrm{H}_{1}$ diterima, yang berarti bahwa "Ada pengaruh intelegensi terhadap hasil belajar". Setelah mendapatkan bahwa ada pengaruh antara intelegensi dan hasil belajar siswa, ditemukan ada satu siswa yang intelegensinya tinggi tetapi hasil belajarnya rendah, lalu siswa ini diwawancarai kembali.

\section{Hasil Wawancara}

Wawancara ini dilakukan dalam 2 kali dan menggunakan jenis wawancara tidak terstruktur. Kali pertama wawancara dilakukan dengan pendidik dan kali kedua wawancara dilakukan dengan siswa yang memiliki hasil tes IQ tinggi tapi hasil belajarnya rendah.

\section{Wawancara dengan pendidik}

P1 : Bagaimana proses pembelajaran matematika disini, bu?

A1-P : Seperti biasanya dek, siswa disini kooperatif.

P2 : Kalau dalam mengerjakan tugas, rajin ji siswanya, bu?

A2-P : Iya mereka selalu mengumpulkan tugas yang saya berikan

P3 : Masalah apa yang sering dihadapi oleh siswa, bu?

A3-P : Kebanyakan dari mereka lebih berfikir secara sintetis.

P4 : Berapa jam pelajaran selama seminggu diberikan untuk kelas VIII, bu?

A4-P : Untuk kelas VIII, di SMP diberikan lima jam pelajaran.

Menurut pendidik, peserta didik yang bersangkutan beberapa terkadang aktif dan kooperatif dalam proses belajar mengajar. Peserta didik dibiasakan berdiskusi di dalam kelas. Dalam hal penugasan, peserta didik yang bersangkutan juga selalu mengerjakan tugas, walaupun itu sudah telat, akan tetapi masih mengumpulkan tugas. Mereka tetap bertanggung jawab dengan tugasnya.

Peserta didik yang bersangkutan juga mempunyai masalah-masalah yang dihadapi, seperti kesalahan penghitungan, penyerapan materi, kebingungan dalam menyelesaikan soal yang berbeda dengan contoh, susah berkonsentrasi, dan lainnya.

\section{Wawancara dengan peserta didik}

P1 : Kenapa begini nilai ta, dek? Pasti ada alasannya ini..

A1 : Nda fokus ka kak, karna tidak sarapan ka juga jadi banyak salah kak

P2 : Susah memang soalnya kah?

A2 : Beuh iyalah kak. Nda begitu suka ka kak sama matematika

P3 : Kalau jam pelajaran bagaimana?

A3 : Jamnya kak masih kurang. Jadi kalau menjelang akhir semester biasanya kejar materi

P4 : Bagaimana dari keluarga ta dek?

A4 : kalo mama papaku kak tidak terlalu kak tapi selalu ka na kontrol hasil belajarku

P5 : Kalau dari gurunya bagaimana?

A5 : Selalu yang pintar ji na bati-bati. Baru malla-mallaka kak kalo mau bertanya 
Dari analisis hasil wawancara dari tiga subjek diatas diperoleh penyebab yang sering dialami oleh subjek adalah malas dalam belajar, kurang berlatih, kurang menguasai materi yang diberikan. Sedangkan faktor yang lainnya dihadapi oleh beberapa subjek yang berbeda.

Dorongan dan motivasi dari orang tua juga menjadi faktor yang dihadapi oleh peserta didik. Orang tua sering memberikan target dan harapan yang menjadi beban mental bagi peserta didik yang berakibat peserta didik menjerumuskan dirinya sendiri untuk tidak mendapatkan hasil yang maksimal. Hubungan antara pendidik dan peserta didik juga masih menjadi problem yang harus dipecahkan, sehingga peserta didik lebih nyaman untuk berkonsultasi dengan pendidik di luar jam pelajaran.

\section{KESIMPULAN}

Kesimpulan yang diperoleh dari penelitian ini yaitu: pada pengujian menggunakan statistik inferensial terdapat pengaruh yang signifikan pada hasil belajar dari ketiga kelompok intelegensi dan menyebabkan peserta didik mempunyai jawaban yang beragam. Hasil belajar matematika siswa berpengaruh jika dikaitkan dengan intelegensi. Beberapa siswa yang memperoleh hasil belajar yang rendah, intelegensinya juga rendah. Begitupun siswa yang hasil belajarnya sedang, intelegensinya juga sedang. Terdapat satu siswa yang intelegensinya tinggi, tetapi memperoleh hasil belajar yang rendah. Siswa ini terpilih untuk diwawancarai mengenai faktor apa yang menyebabkan hal ini terjadi. Peserta didik merasa bebas dari orang tua sehingga terlena dengan kebebasan yang diberikan. Selain itu orang tua yang kurang tegas dalam pendidikan peserta didik, sehingga peserta didik kurang bersemangat dalam belajar.

\section{DAFTAR PUSTAKA}

Aji, M.R. (2012). Analisis Faktor Penyebab Peserta Didik dengan Kecerdasan Intelegensi (IQ) Tinggi Memperoleh Hasil Belajar Rendah (Sudi Kasus di Kelas XI IPA 4 \& XI IPA 5 MAN 1 Semarang Tahun Ajaran 2011/2012). IAIN Walisongo, Semarang.

Chaplin, J.P. (2005). Kamus Lengkap Psikologi. Jakarta: Rajawali Press.

Clark, R. (1981). Cognitive Prespective Theory and Psyco Educational Design. California: University of Southern California.

Fauzan, J. (2011). Pengaruh Kecerdasan Intelegensi Terhadap Hasil Belajar Matematika. Universitas Pancasakti Tegal, Jawa Tengah.

Janah, Miftahul. (2014). Analisis Faktor Penyebab Peserta Didik Dengan Kecerdasan Intelegensi (IQ) Tinggi Memperoleh Hasil Belajar Matematika Rendah. Universitas Muhammadiyah Surakarta, Jawa Tengah.

Prianto, H. (2013). Peningkatan Hasil Belajar Matematika Melalui Pendekatan Matematika Realistik (PMR) Siswa Kelas 2 MI Al-Hakim Geger Madiun Tahun Ajaran 2012/2013. Jurnal Ilmiah Pendidikan Universitas Doktor Nugroho, 1(1). 91-104.

Putra, Z.N., Sucitra, W. (2015). Hubungan Intelegensi dengan Hasil Belajar Matematika Siswa Kelas V SDN 68 Pekanbaru. Jurnal Pendidikan Matematika IAIN Antasari, 02(2). 1-18.

Sudjana, N. (2005). Penilaian Hasil Proses Belajar Mengajar. Bandung: PT. Remaja Rosdikarya

Suhendri, H. (2011). Pengaruh Kecerdasan Matematis-Logis dan Kemandirian Belajar Terhadap Hasil Belajar Matematika. Jurnal Formatif Universitas Indraprasta PGRI, 1(1). 29-39.

Sukiarti, N.K. (2005). Pengaruh Tingkat Intelegensi dan Motivasi Belajar. UNNES Press, Semarang. 